\title{
THE EVALUATION OF SELECTED GHANAIAN MEDICINAL PLANTS FOR CYTOTOXIC ACTIVITIES
}

\author{
M.T. Bayor ${ }^{1,2}$, J.S.K. Ayim ${ }^{1}$, R.M. Phillips' ${ }^{2}$, S.D. Shnyder ${ }^{2}$ and C.W. Wright ${ }^{3}$ \\ ${ }^{1}$ Faculty of Pharmacy, KNUST, Kumasi, Ghana, \\ ${ }^{2}$ Institute of Cancer Therapeutics, U.K. \\ ${ }^{3}$ School of Pharmacy, University of Bradford, West Yorkshire, BD7 1DP, UK.
}

\begin{abstract}
Cancer is still responsible for many deaths worldwide. Therefore, the need for an effective management, treatment and cure of cancer is undoubtedly crucial. In Ghana, several plants or herbal products are used by traditional healers for the management and/or the treatment of various cancers. However, the efficacies of these plant products as anticancer agents are often ill defined. In this study, the methanolic extracts of ten plant species were evaluated for cytotoxicity against three human cancer cell lines, DLD-1, MCF-7 and M14, using the MTT assay. Extracts of Adenia lobata root, Clerodendrum capitatum leaves, Garcinia kola stem bark, Plumbago zeylanica leaves and Vernonia conferta root, showed relatively low cytotoxic activities while extracts of Ficus asperifolia leaves, Paullinia pinnata root and Thonningia sanguinea root exhibited moderate activity $\left(\right.$ IC $_{50}$ values $40-55 \mu \mathrm{g} / \mathrm{ml}$ against at least one of the three cell lines). Croton membranaceus root extract exhibited markedly higher cytotoxic activities, particularly against the DLD-1 and MCF-7 cells $\left(I C_{50}=16.0\right.$ and $17.4 \mu \mathrm{g} / \mathrm{ml}$ respectively), while Zanthoxylum xanthoxyloides bark extract was 2-3 fold more active against DLD-1 cells $\left(I C_{50}=16 \mu \mathrm{g} / \mathrm{ml}\right)$, than against the other cell lines. These results lend some support for the use of these species in traditional medicines for the treatment of cancer, especially for $C$. membranaceus and Z. xanthoxyloides.
\end{abstract}

Keywords: Cytotoxicity, anticancer activity, medicinal plants, MTT assay

\section{INTRODUCTION}

Cancer is described as an ancient disease ubiquitous in human society and capable of affecting any part of the body. Cancer is still increasingly responsible for many deaths worldwide. Therefore, the need for an effective management, treatment and cure of cancer is undoubtedly cru- cial. Plants are an obvious source of diverse compounds which may serve as drugs or lead compounds for the development of more effective anticancer agents. In Ghana, several plants or herbal products are used by herbalists and traditional healers for the management and/or treatment of various cancers (Mshana et al., 2000),

16 Journal of Science and Technology, Vol. 27, No. 3, December 2007 
but there have been few studies on the activity, efficacy and potency of these plant products as anticancer agents.

In this paper we report our investigations into the cytotoxic activities of ten Ghanaian medicinal plants in order to assess their potential for evaluation as anticancer agents. These plants are used in Ghanaian herbal and traditional medicine for the treatment and management of various cancers and other diseases (Hutchinson and Dalziel, 1958; Irvine, 1961; Mshana et al., 2000). Their methanolic extracts were screened for cytotoxic activities on three human cancer cell lines.

\section{MATERIALS AND METHODS \\ Plant Material}

The plant materials used in this study (Table 1) were obtained from Mampong-Akwapem, the botanical gardens of KNUST and the medicinal plants garden of the Faculty of Pharmacy, KNUST. These materials were authenticated at the Centre for Scientific Research into Plant Medicine (CSRPM), Mampong-Akwapem, the Forestry Commission, Kumasi, and the Faculty of Pharmacy, KNUST, Kumasi, where voucher specimens are deposited. The materials were dried in the shade and comminuted into suitably sized particles for extraction.

\section{Extraction of Plant Material}

The methanolic extracts of the powdered plant parts were obtained by repeated cold maceration using $100 \mathrm{~g}$ of each plant material. The extracts were pooled and concentrated to a syrupy mass under reduced pressure in a rotary evaporator. These extracts were then dried completely over silica gel in a vacuum chamber at room temperature. The dried extracts were stored in a refrigerator until required for use.

\section{Biological Evaluation of the Extracts}

Human cancer cell lines, DLD-1 (colon), MCF-7 (breast) and M14 (melanoma) were available at the University of Bradford. Cells were washed with Hanks Balanced Salt Solution (HBSS), cultured in complete RPMI 1640 medium $\left(37^{\circ} \mathrm{C}, 5 \%\right.$ $\mathrm{CO}_{2}, 95 \%$ air, $100 \%$ relative humidity), and used for bioasssays after the second passage but not beyond eight passages. Cells were grown in complete RPMI 1640 medium and inoculated into 96well microtiter plates in $180 \mu 1$ medium at plating densities ranging from 5,000 to 40,000 cells/well depending on the doubling time of individual cell lines. After cell inoculation, the microtiter plates were incubated at $37^{\circ} \mathrm{C}$, in an atmosphere of $5 \%$ $\mathrm{CO}_{2}, 95 \%$ air and $100 \%$ relative humidity for 24 hours prior to addition of experimental drugs. The experimental drugs/extracts were solubilized in dimethylsulfoxide (DMSO) at 400-fold the desired final maximum test concentration and stored frozen prior to use. At the time of drug addition,

Table 1: Species and parts of plants used in this study

\begin{tabular}{ll}
\hline Species and family & Part tested \\
\hline Adenia lobata (Jacq.) Engl. (Passifloraceae) & Root \\
Croton membranaceus Mull. Arg. (Euphorbiaceae) & Root \\
Clerodendrum capitatum Willd. (Verbenaceae) & Leaves \\
Ficus asperifolia Miq. (Moraceae) & Leaves \\
Garcinia kola (Guttiferae) & Stem Bark \\
Paullinia pinnata Linn. (Sapindaceae) & Root \\
Plumbago zeylanica Linn. (Plumbaginaceae) & Leaves \\
Thonningia sanguinea Vahl (Balanophoraceae) & Root \\
Vernonia conferta Benth. (Asteraceae) & Root \\
Zanthoxylum xanthoxyloides Lam. (Rutaceae) & Bark \\
\hline
\end{tabular}


the frozen drug concentrates were thawed and diluted to 10 -fold the desired final test concentrations with complete medium. The final concentrations of DMSO were not more than $0.1 \%$ (which was shown to have no effect on cell viability and growth). Aliquots, $(20 \mu \mathrm{l})$ of these different drug dilutions were added to the appropriate microtiter wells already containing cells and medium, resulting in the required final drug concentrations, while $20 \mu \mathrm{l}$ aliquots of complete medium were added to the blank and untreated control wells. Doxorubicin (adriamycin), 5fluorouracil and etoposide were used as positive control drugs. Following drug addition, the plates were incubated for an additional 4 days. After discarding the supernatant, $200 \mu \mathrm{l}$ of a $0.1 \mathrm{mg} / \mathrm{ml}$ solution of MTT [3-(4,5-dimethylthiazol-2-yl)-2,5-diphenyltetrazolium bromide) in saline, was added to each well, and the plates re-incubated for 4 hours (Carmichael et al., 1987). Following this, the supernatants were discarded, the blue formazan crystals dissolved with $150 \mu \mathrm{l}$ of DMSO per well, and the absorbance read on an automated plate reader at 540nm. Graphical plots of percent cell growth compared to control culture wells against con- centration of extract/drug were made from which the $\mathrm{IC}_{50}$ values for each extract/drug were obtained through regression analysis of the results of at least five different concentrations of each extract/drug. At least three independent assays were conducted for each experimental agent.

\section{RESULTS AND DISCUSSION}

The effects of the plant extracts on the growth of the three cell lines are shown in table 2. The extract of $A$. lobata root, showed low cytotoxic activities against the three cell lines used, giving $\mathrm{IC}_{50}$ values of 170,230 and above $300 \mu \mathrm{g} / \mathrm{ml}$ for DLD-1, MCF-7 and M14 respectively. A cytotoxic polyacetylene (gummiferol) was reported from the leaves of the related species A. gummifera with activity against KB human cell line and other human cancer cell lines (Fullas et al., 1995).

C. membranaceus root extract exhibited activity on all the three cell lines. The $\mathrm{IC}_{50}$ values of the extract were; $16,17.4$ and $33.5 \mu \mathrm{g} / \mathrm{ml}$ for DLD-1, MCF-7, and M14 respectively. Although the activity of the extract on M14 cells $(33.5 \mu \mathrm{g} / \mathrm{ml})$ differed slightly from those of DLD-1 $(16 \mu \mathrm{g} / \mathrm{ml})$ and MCF-7 $(17.4 \mu \mathrm{g} / \mathrm{ml})$, the results seem to sug-

Table 2: Cytotoxic activities of crude methanolic plant extracts and standard cytotoxic drugs against DLD-1, MCF-7 and M14, cells

\begin{tabular}{llll}
\hline Plant species/Drug & \multicolumn{1}{c}{ DLD-1 } & $\begin{array}{c}{\left[\mathbf{I} \mathbf{5 0}_{\mathbf{5 0}}, \mathbf{m g} / \mathbf{m l} \pm \mathbf{S D}\right]} \\
\mathbf{M C F}-\mathbf{7}\end{array}$ & $\mathbf{M} \mathbf{1 4}$ \\
\hline Adenia lobata & $170 \pm 3.5$ & $230 \pm 1.2$ & $>300$ \\
Croton membranaceus & $16.0 \pm 1.0$ & $17.4 \pm 1.6$ & $33.5 \pm 0.5$ \\
Clerodendrum capitatum & $86.5 \pm 5.2$ & $80 \pm 4.0$ & $128 \pm 2.0$ \\
Ficus asperifolia & $45 \pm 1.0$ & $49 \pm 3.2$ & $83.7 \pm 1.6$ \\
Garcinia kola & $112 \pm 4.5$ & $212 \pm 1.8$ & $210 \pm 3.7$ \\
Paullinia pinnata & $52 \pm 2.5$ & $55 \pm 0.5$ & $>100$ \\
Plumbago zeylanica & $68 \pm 3.4$ & $84.5 \pm 3.8$ & $>100$ \\
Thonningia sanguinea & $40 \pm 1.0$ & $55 \pm 1.2$ & $43.2 \pm 2.0$ \\
Vernonia conferta & $92.5 \pm 2.6$ & $235 \pm 3.5$ & $283 \pm 1.5$ \\
Zanthoxylum xanthoxyloides & $16 \pm 1.8$ & $43.3 \pm 3.1$ & $44.3 \pm 1.5$ \\
5-Fluorouracil & $1.5 \pm 1.0$ & $2.5 \pm 0.5$ & $27.5 \pm 1.2$ \\
Doxorubicin & $0.6 \pm 0.1^{\mathrm{a}}$ & $0.4 \pm 0.2^{\mathrm{a}}$ & $1.0 \pm 1.5^{\mathrm{a}}$ \\
Etoposide & $2.0 \pm 1.0$ & $1.8 \pm 1.4$ & $5 \pm 1.2$ \\
\hline
\end{tabular}

${ }^{\mathrm{a}}$ value in $\mathrm{ng} / \mathrm{mL}$ 
gest a general cytotoxicity and growth inhibitory activity against the cell lines, rather than a selective activity against DLD-1 and MCF-7. Several other species of Croton have been shown to have cytotoxic properties and a number of active diterpenes have been isolated including dehydrocrotinin from the bark of Croton cajucara Benth., which has been reported to have antitumour efficacy both in vitro and in vivo (Melo et al., 2004). Also, two halimane diterpenoids (crotohalimaneic acid and crotohalimoneic acid) from $C$. oblongifolius, have been reported to have potent cytotoxic activities against a panel of human tumour cell lines (Roengsumran et al., 2004).

The activity of the extract of Clerodendrum capitatum leaves, gave $\mathrm{IC}_{50}$ values of $86.5,80$ and $128 \mu \mathrm{g} / \mathrm{ml}$ against DLD-1, MCF-7 and M14 respectively. Cytotoxic pheophorbide-related compounds obtained from the related species $C$. calamitosum and C. cyrtophyllum exhibited strong cytotoxicity against various human cancer cell lines as reported by Cheng et al (2001).

The results obtained with the methanolic extract of Ficus asperifolia leaves, indicated modest activity especially against DLD-1 $(45 \mu \mathrm{g} / \mathrm{ml})$ and MCF-7 $(49 \mu \mathrm{g} / \mathrm{ml})$ and these species may merit further investigation especially as some other species of Ficus have shown interesting activities. Isolates from the leaves of $F$. septica exhibited strong cytotoxic activity against two human cancer cell lines, NUGC and HONE-1 (Wu et al., 2002), and an extract of F. citrifolia was reported to modulate cancer cell multidrug resistance which suggested that the latter species has therapeutic potential for improving the efficacy of cancer chemotherapy (Simon et al., 2001).

The cytotoxic activities of Garcinia kola stem bark extract were weak $\left(\mathrm{IC}_{50}\right.$ values of 112.5, 212.5 and $210.8 \mu \mathrm{g} / \mathrm{ml}$ for DLD-1, MCF-7 and M14 respectively), but it is possible that $G$. kola may act as a chemopreventive agent due to its antioxidant and scavenging properties on free radicals and active oxygen species (Farombi et al., 2002). The crude methanolic extract of the pericarp of $G$. mangostana showed potent antiproliferative and antioxidant activities and induced apoptosis in human breast cancer (SKBR3) cells, exhibiting a similar potential for cancer chemoprevention (Moongkarndi et al., 2004a). Similarly, the polyphenolic compounds from the fruits of Garcinia strongly inhibited the growth of human colon cancer cells by GI/S arrest and apoptosis (Protiva et al., 2003). However, specific cytotoxicities have been reported for other species of Garcinia. Polyprenylated xanthonoids from $G$. gaudichaudii have been shown to exhibit significant cytotoxicity against several cancer cell lines (Cao et al., 1998). Also, garcinone-E (a xanthone derivative) from $G$. mangostana, reportedly has potent cytotoxic effect on all human colon cancer cell lines as well as on other gastric and lung cancers (Ho et al., 2002).

$P$. pinnata root extract produced activity fairly similar to those of $F$. asperifolia leaf extract, with $\mathrm{IC}_{50}$ values of 52,55 and slightly above $100 \mu \mathrm{g} / \mathrm{ml}$ for the respective three cell lines; DLD-1, MCF-7 and M14. The results of the extract (especially on DLD-1 and MCF-7), may be sufficient to suggest some basis for its use traditionally. Similar investigations involving the aqueous extract of $P$. $\mathrm{Cu}$ pana (guarana), evaluated for toxicity on Chinese hamster ovary (CHO) cells and bacterial cells (Photobacterium phosphoreum) indicated low cytotoxicity, requiring high doses of extract for cytotoxic activity (Santa et al., 1998).

The $\mathrm{IC}_{50}$ values obtained from $P$. zeylanica leaf extract, against the three cell lines DLD-1, MCF7 and M14 were; 68, 84.5 and $>100 \mu \mathrm{g} / \mathrm{ml}$ respectively. The low activity could however, be due to the fact that the cytotoxic constituents are less concentrated in the leaves compared to the roots, since plumbagin (a naphthoquinone) isolated from the roots is reported to have significantly suppressed the growth of Raji, Calu-1, HeLa and Wish tumour cell lines (Parimala and Sachdanandam, 1993), and also exhibited anticarcinogenic properties (through induced tumour regression) against 3-methyl-4-dimethylaminoazobenzene- 
induced hepatoma in Wistar male rats (Lin et al., 2003).

The extract of $T$. sanguinea root, gave results with relatively similar $\mathrm{IC}_{50}$ values for all the three cell lines used, namely; DLD-1 $(40 \mu \mathrm{g} / \mathrm{ml})$, MCF7 $(55 \mu \mathrm{g} / \mathrm{ml})$ and M14 $(43.2 \mu \mathrm{g} / \mathrm{ml})$. The extract therefore exhibited a non-selective cytotoxicity against the cell lines used and may be worthy of further investigation. This species has also been reported to have antioxidant activity, which protects against induced liver injuries and aflatoxin B-1-induced acute hepatotoxicity in rats (Gyamfi and Aniya, 1998).

$V$. conferta root extract also exhibited little/low anticancer activity against all the three cell lines $\left(\mathrm{IC}_{50}\right.$ values $=92.5 \mu \mathrm{g} / \mathrm{ml}, 235 \mu \mathrm{g} / \mathrm{ml}$ and $283 \mu \mathrm{g} /$ $\mathrm{ml}$ for DLD-1, MCF-7 and M14 cells respectively, although some other species of Vernonia have been reported to have cytotoxic properties. The water-soluble leaf extract of $V$. amygdalina was reported to be a potent inhibitor of DNA synthesis in MCF-7 cells (Izevbigie, 2003; Izevbigie et al., 2004). The activity of the $V$. amygdalina extract has been said to support the modulation of CYP3A4 expression in response to cancer treatment which is relevant to prognosis (Howard et al., 2003). Also, two elemanolides (epivernodalol and lasiopulide) isolated from $V$. lasiopus, have reportedly shown in vitro cytotoxicity against human cancer cell lines in culture (Koul et al., 2003). Similarly, the two novel sesquiterpene lactones, vernolide-A and vernolide-B, from $V$. cinerea have demonstrated potent cytotoxicity against human KB, DLD-1, NCI-661 and Hela tumour cell lines (Kuo et al., 2003).

The extract of Z. xanthoxyloides bark, showed some level of activity against all the three cell lines in the screen, with $\mathrm{IC}_{50}$ values of $16 \mu \mathrm{g} / \mathrm{ml}$ (DLD-1), $43.3 \mu \mathrm{g} / \mathrm{ml}$ (MCF-7) and $44.3 \mu \mathrm{g} / \mathrm{ml}$ (M14). Therefore, the extract was 2-3 fold more active against DLD-1 cells than against the other two cell lines, giving some indication of a selective cytotoxicity. The petroleum ether extract of Z. rhesta (Monira et al., 2000) and the methano- lic extract of the bark of Z. budrunga (Islam et al., 2001), exhibited significant toxic activity on brine shrimp (Artemia salina) nauplii. Also, isolates from Z. pistaciiflorum (Chen et al., 2004) have shown effective cytotoxicities against P-388 and HT-29 cell lines in vitro.

In summary, the extracts of $A$. lobata root, $C$. capitatum leaves, $G$. kola stem bark, $P$. zeylanica leaves and $V$. conferta root, showed little cytotoxic activity with $\mathrm{IC}_{50}$ values of $68 \mu \mathrm{g} / \mathrm{ml}$ or above. The extracts of $F$. asperifolia leaves, $P$. pinnata root and $T$. sanguinea root however, exhibited moderate activities, giving $\mathrm{IC}_{50}$ values in the range of $40-55 \mu \mathrm{g} / \mathrm{ml}$ against at least one cell line. The extracts of $C$. membranaceus root and Z. xanthoxyloides bark displayed marked cytotoxic activities on at least one of the three cell lines with $\mathrm{IC}_{50}$ values from $16 \mu \mathrm{g} / \mathrm{ml}$ to $44.3 \mu \mathrm{g} /$ $\mathrm{ml}$, with both extracts having the same value $(16 \mu \mathrm{g} / \mathrm{ml})$ on DLD-1 cells. The extract of $Z$. xanthoxyloides bark indicated a rather selective activity towards DLD-1 cells, while the Croton membranaceus root extract had a general cytotoxic activity against all the three cell lines used in the screen. These results lend some support for the use of these species in traditional medicines for the treatment of cancer, especially $C$. membranaceus and $Z$. xanthoxyloides; further work on these plants would be worthwhile.

\section{ACKNOWLEDGEMENT}

MTB thanks the Commonwealth Scholarship Commission (UK), for the award of a scholarship.

\section{REFERENCES}

Cao, S.G., Sng, V. H. L., Wu, X. H., Sim, K. Y., Tan, B. H. K., Pereira, J. T. and Goh, S. H. (1998). Novel cytotoxic polyprenylated xanthonoids from Garcinia gaudichaudii (Guttiferae). Tetrahedron, 54 (36): 1091510924.

Carmichael, J., DeGraff, W.G., Gazdar, A. F., Minna, J. D. and Mitchell, B. (1987). Evaluation of tetrazolium based semiautomated colometric assay; assessment of chemosensitivity testing. Cancer Research, 47: 936. 
Chen, J. J., Huang, H. Y., Duh, C. Y. and Chen, L. S. (2004). Cytotoxic constituents from the stem bark of Zanthoxylum pistaciiflorum. Journal of the Chinese Chemical Society, 51 (3): 659-663.

Cheng, H. H., Wang, H. K., Ito, J., Bastow, K. F., Tachibana, Y., Nakanishi, Y., Xu, Z. H., Luo, T. Y. and Lee, K. H. (2001). Cytotoxic pheophorbide-related compounds from Clerodendrum calamitosum and C. cyrtophyllum. Journal of Natural Products, 64 (7): 915-919.

Farombi, E.O., Akanni, O.O. and Emerole, G.O. (2002). Antioxidant and scavenging activities of flavonoid extract (kolaviron) of Garcinia kola seeds. Pharmaceutical Biology, 40 (2): 107-116.

Fullas, F., Brown, D. M., Wani, M. C., Wall, M. E., Chagwedera, T. E., Farnsworth, N. R., Pezzuto, J. M. and Kinghorn, A. D. (1995). Gummiferol, a cytotoxic polyacetylene from the leaves of Adenia gummifera. Journal of Natural Products, 58 (10): 1625-1628.

Gyamfi, M. A. and Aniya, Y. (1998). Medicinal herb, Thonningia sanguinea protects against aflatoxin B-1 acute hepatotoxicity in Fischer 344 rats. Human \& Experimental Toxicology, 17 (8): 418-423.

Ho, C. K., Huang, Y. L. and Chen, C. C. (2002). Garcinone E, a xanthone derivative, has potent cytotoxic effect against hepatocellular carcinoma cell lines. Planta Medica, 68 (11): 975-979.

Howard, C. B., Stevens, J., Izevbigie, E. B., Walker, A. and McDaniel, O. (2003). Time and dose-dependent modulation of phase 1 and phase 2 gene expression in response to treatment of MCF-7 cells with a natural anticancer agent. Cellular and Molecular Biology, 49 (7): 1057-1065.

Hutchinson, L. J. and Dalziel, J. M. (1958). Flora of West Tropical Africa. Revised by R. W. J. Keay. $2^{\text {nd }}$ ed. Vol. 1, Part 2. White Press, London. p.393.
Irvine, F. R. (1961). Woody plants of Ghana. Oxford University Press, London. p.321.

Islam, A. S., Bhuiyan, M. S. A., Mosaddik, M. A., Islam, M. A. U. and Astaq Mondal Khan, G. R. M. (2001). Antimicrobial activity and cytotoxicity of Zanthoxylum budrunga. Fitoterapia, 72 (4): 428-430.

Izevbigie, E. B. (2003). Discovery of watersoluble anticancer agents (edotides) from a vegetable found in Benin City, Nigeria. Experimental Biology and Medicine, 228 (3): 293-298.

Izevbigie, E. B., Bryant, J. L. and Walker, A. (2004). A novel natural inhibitor of extracellular signal-regulated kinases and human breast cancer cell growth.

Experimental Biology and Medicine, 229 (2): 163-169.

Koul, J. L., Koul, S., Singh, C., Taneja, S. C., Shanmugavel, M., Kampasi, H., Saxena, A. K. and Qazi, G. N. (2003). In vitro cytotoxic elemanolides from Vernonia lasiopus. Planta Medica, 69 (2): 164-166.

Kuo, Y. H., Yu, A. S., Wu, M. D., Ong, C. W., Kuo, L. M. Y., Huang, J. T., Chen, C. F. and Li, S. Y. (2003). Two novel sesquiterpene lactones, cytotoxic vernolide-A and -B, from Vernonia cinerea. Chemical \& Pharmaceutical Bulletin, 51 (4): 425-426.

Lin, L. C., Yang, L. L. and Chou, C. J. (2003). Cytotoxic naphthoquinones and plumbagic acid glucosides from Plumbago zeylanica. Phytochemistry, 62 (4): 619-622.

Melo, S. P., Justo, Z. G., Durán, N. and Haun, M. (2004). Natural killer cell activity and antitumour effects of dehydrocrotonin and its synthetic derivatives. European Journal of Pharmacology, 487: 47-54.

Monira, A., Tahmina, A. Z., Choudhury, M. H., Chihiro, I. and Nazrul Islam S. K. (2000). Constituents and cytotoxicity of Zanthoxylum rhesta stem bark. Fitoterapia, 71 (6): 697-700. 
Moongkarndi, P., Kosem, N., Luanratana, O., Jongsomboonkusol, S. and Pongpan, N. (2004a). Antiproliferative activity of Thai medicinal plant extracts on human breast adenocarcinoma cell line. Fitoterapia, 75 (34): $375-377$.

Moongkarndi, P., Kosem, N., Kaslungka, S., Luanratana, O., Pongpan, N. and Neungton N. (2004b). Antiproliferation, antioxidation and induction of apoptosis by Garcinia mangostana (mangosteen) on SKBR3 human breast cancer cell line. Journal of Ethnopharmacology, 90 (1): 161-166.

Mshana, N. R., Abbiw, D. K., Addae-Mensah, I., Adjanouhoun, E., Ahyi, M. R. A., Ekpere, J. A., Enow-Orock, E. G., Gbile, Z. O., Noamesi, G. K., Odei, M. A., Odunlami, H., Oteng-Yeboah, A.A., Sarpong, K., Sofowora, A. and Tackie, A. N. (2000). Traditional medicine and pharmacopoeia: contribution to the revision of ethnobotanical and floristic studies in Ghana. Organization of African Unity/Scientific, Technical and Research Commission (OAU/STRC).

Parimala, R. and Sachdanandam, P. (1993). Effect of plumbagin on some glucose metabolizing enzymes studied in rats in experimental hepatoma. Molecular and Cellular Biochemistry, 125 (1): 59-63.
Protiva, P., Kennelly, E., Baggett, S., Ma, J., Holt, P. R. and Weinstein, I. B. (2003). Polyphenolic compounds from the fruit of Garcinia strongly inhibit the growth of human colon cancer cells by G1/S arrest and apoptosis. Gastroenterology, 124 (4): A463-A463 Suppl. S.

Roengsumran, S., Pornpakakul, S., Muangsin, N., Sangvanich, P., Nhujak, T., Singtothong, P., Chaichit, N., Puthong, S. and Petsom, A. (2004). New halimane diterpenoids from Croton oblongifolius. Planta Medica, 70 (1): 87 89.

Santa M. A., Lopez, A., Diaz, M. M., MunozMingarro, D. and Pozuelo, J. M. (1998). Evaluation of the toxicity of guarana with in vitro bioassays. Ecotoxicology and Environmental Safety, 39 (3): 164-167.

Simon, P. N., Chaboud, A., Darbour, N., Di Pietro, A., Dumontet, C., Lurel, F., Raynaud, J. and Barron, D. (2001). Modulation of cancer cell multidrug resistance by an extract of Ficus citrifolia. Anticancer Research, 21 (2A): 1023-1027.

Wu, P. L., Rao, K. V., Su, C. H., Kuoh, C. S. and Wu, T. S. (2002). Phenanthroindolizidine alkaloids and their cytotoxicity from the leaves of Ficus septica. Heterocycles, 57 (12): 2401 2408. 